\title{
Application of PCSWMM to Assess Wastewater Treatment and Urban Flooding Scenarios in Phnom Penh, Cambodia: A Tool to Support Eco-City Planning
}

\author{
Kim N. Irvine, ${ }^{1}$ Chansopheaktra Sovann, ${ }^{2}$ Sthiannopkao Suthipong, ${ }^{3}$ Sothea $\mathrm{Kok}^{2}$ and Eliyan $\mathrm{Chea}^{2}$ \\ ${ }^{1}$ Nanyang Technological University, Singapore; ${ }^{2}$ Royal University of Phnom Penh, Phnom Penh, Cambodia; ${ }^{3}$ Dong-A University, Busan, Republic
} of Korea.

Received 2015-04-10, accepted 2015-06-30, published 2015-08-15.

\begin{abstract}
Eco-city philosophy and urban sustainability have been increasingly incorporated into planning and policy making. Often, system sustainability and resilience are assessed using a simple index approach, which can be helpful in measuring changes over time or in a comparative evaluation of cities, but is less helpful in guiding specific policy and design decisions. To this end, we illustrate the application of a dynamic water resource model which can complement an index analysis. Specifically, a personal computer (PC) version of the Stormwater Management Model (PCSWMM) was used to explore different wastewater treatment and urban flood management scenarios for Phnom Penh, Cambodia. Currently wastewater in Phnom Penh is treated effectively using sustainable, naturally occurring wetlands. Urban expansion is placing increasing pressure on these wetlands and PCSWMM results showed that infilling of the largest wetland by up to $22 \%$ could have a negative impact on treatment, but the system still would function. The alternative of activated sludge treatment is shown to be costly and energy intensive. Impacts of infilling on the large peri-urban community living on the wetland and to other ecosystem services were not assessed. Increased pump capacity at the existing stations would reduce, but not eliminate, local surface flooding. More sustainable, eco-friendly low impact development technologies should be considered in addition to hard engineering to reduce surface flooding.
\end{abstract}

\section{Introduction}

Yokohari et al. (2000) observed that explosive urban expansion throughout Asia has resulted in serious environmental problems, including air and water quality issues, and inadequate infrastructure; Varis, Biswas et al. (2006) mark similar challenges for megacities globally. Zhao et al. (2006) reported that $<50 \%$ of the domestic wastewater in Asia is treated, compared with $80 \%$ in the developed world. Furthermore, $>95 \%$ wastewater from Asian cities is discharged directly into receiving waters without any treatment. Given this treatment situation perhaps it is not surprising that the diarrhoea burden in Southeast Asia, as reflected by mortality and disability-adjusted life years (DALYS), is second behind sub-Saharan Africa in the regional analysis recently conducted by Pruss-Ustun et al. (2014).

Although the interactions are complex and there is a need for more research, it seems that environmentally sensitive urban design can have a positive impact on human health (Jackson 2003; Northridge et al. 2003; Tzoulas et al. 2007; Vlahov et al. 2007). Kenworthy (2006) noted "Making existing cities and new urban development more ecologically based and liveable is an urgent priority in the global push for sustainability." $\mathrm{Ng}$ and Hills (2003) argued that much research had focused on ranking world cities with respect to their economic health, but little work had addressed the comparative sustainability of these same cities, although more recently such comparisons are starting to be undertaken (e.g. Shen et al. 2011). The concept of eco-city planning appears to have been established in North America during the mid-1970s with the Urban Ecology group in Berkeley, California (Roseland 1997). The primary guiding principle for eco-city planning is the belief that cities should function in the same way as a natural ecosystem and reflect natural patterns of sustainability (Wittig 2008; Wong and Yuen 2011). An important element of eco-city planning is the use of appropriate green technologies for

Irvine, K., C. Sovann, S. Suthipong, S. Kok and E. Chea. 2015. "Application of PCSWMM to Assess Wastewater Treatment and Urban Flooding Scenarios in Phnom Penh, Cambodia: A Tool to Support Eco-City Planning." Journal of Water Management Modeling C389. doi: 10.14796/JWMM.C389.

(c) CHI 2015 www.chijournal.org ISSN: 2292-6062 
water, energy and waste management (Kenworthy 2006; Wong and Yuen 2011). Although the philosophical roots of eco-city planning may date to the mid-1970s, Joss (2010) observed that until the mid-2000s, there were relatively few concrete examples of true eco-city planning, but with increasing concerns about climate change and rapid urbanization in the developing world, there has since been a proliferation of eco-city initiatives. Wong and Yuen (2011) provided detailed examples of the global diffusion in eco-city planning and it seems that such planning has become embedded within mainstream policy making throughout the world.

Various approaches have been considered in assessing urban water resources, sustainability and urban resiliency, including life cycle assessment and pressure-state-response frameworks (e.g. Petit-Boix et al. 2014; Ravetz 2000; Sahely et al. 2005), athough the indicator approach seems to have become most popular (Ciegis et al. 2009; Ding et al. 2014; Irvine 2013; Mori and Christodoulou 2012; Reed et al. 2006; Shen et al. 2011; van Leeuwen et al. 2012). Most assessments using an indicator approach follow the three pillar or triple bottom line concept of sustainability that considers three types of capital: social, economic and environmental. In their review of five national scale indicator studies, Eriksen and Kelly (2007) found obvious differences, but also some similarities, specifically the common use of three variables (indicators): access to water or sanitation; per capita GDP; and infant mortality. The comparison also found that relatively few of the indicators reflected institutional conditions, even though Burch (2010) noted that institutional factors may produce important barriers to implementing policies oriented towards sustainability and resiliency. In fact, Mori and Christodoulou (2012) concluded a new sustainability index needed to be created for cities as they identified a number of shortcomings in their review of more than ten existing indexes.

Sahely et al. (2005) examined sustainability criteria specifically for urban infrastructure systems and developed a set of indicators that included consideration of energy consumption, chemical use, greenhouse gas emissions, capital, operations and maintenance costs, service interruptions, and system leakage. Most of the indicators had time series data available that facilitated the tracking of temporal trends, although Sahely et al. (2005) also noted they were not able to fully quantify the social indicators within their study. Probably this not surprising, as while there clearly is a need for interdisciplinary, multidisciplinary and transdisciplinary approaches in sustainability research (Clark and Dickson 2003; Schoot Uiterkamp and Vlek 2007), many have documented the barriers, as well as some of the bridges, to an integrated approach that improves research, and ultimately informs policy (Axelsson 2010; Heberlein 1988; Lowe and Phillipson 2009; Roughly and Salt 2005). More recently, the City Blueprints project identified a set of 24 indicators that could be used "as a first step in the process of understanding, envisioning, developing and implementing measures to transform the water management of cities" (van Leeuwen et al. 2012). In this study, social indicators included the existence of management and action plans and a measure of community volunteerism. Subsequently, van Leeuwen (2013) applied these indicators to compare the sustainability of water management across eleven cities in Europe and Africa.

At a larger spatial scale than the urban environment, some interesting and innovative work on integrating hydrologic, water quality, and socio-economic data in support of management plans for the Tonle Sap Lake system in Cambodia has been done, particularly through WUP-FIN (Water Utilization Program-Finland), an independent program coordinated with the Mekong River Commission (Keskinen 2006; Keskinen et al. 2005; Kummu et al. 2006; Varis, Kummu et al. 2006). This program utilized a suite of hydrologic, hydraulic, and water quality models to provide extensive information about the physical dynamics of the water resource system, although Johnston and Kummu (2012) noted that quantitative modeling in the ecological and social spheres has not progressed as far, with geo-spatial analysis and qualitative frameworks being the most commonly used tools.

The question is, then, how can we encourage and support the progress of cities in Southeast Asia along a more sustainable path? While an indicator approach can facilitate between-city comparisons and identify temporal trends for a particular city to generally assess progress towards sustainability, it is less helpful for municipal planners making decisions regarding specific development options. As such, we argue it is worthwhile to concomitantly explore the use of dynamic modeling (i.e. representing time dependent changes in the system) tools to support such planning and decision making. However, this will require engineers, scientists, social scientists and urban planners to work collectively, along the lines of the example provided by the WUPFIN project.

Accordingly, this paper applies a personal computer (PC) version of the Stormwater Management Model (PCSWMM) to explore options for sustainable wastewater treatment and to reduce localized flooding in the city of Phnom Penh, Cambodia. PCSWMM is a dynamic urban water quantity and quality model that has been applied throughout the world (see more than 20 years of papers from the forerunning monograph series, newly evolved into the Journal of Water Management Modeling at https://www.chijournal.org/), although such modeling is less commonly done in Southeast Asia, with the exception of Singapore (e.g. Chaosakul et al. 2013; Chow et al. 2012; Shrestha et al. 2014; Sothea et al. 2010; Talei and Chua, 2012). PCSWMM explicitly represents surface hydrology, routes flow and water quality constituents through a sewer system, and is capable of representing storage and treatment processes. Through a case study-scenario based approach, it is the objective of this paper to show how a dynamic model, such as PCSWMM, can be useful in supporting decision making that follows sustainability principles. It is important to note that there are a number of dynamic water quantity and quality models available. Because our team is familiar with PCSWMM and it offers advantages with respect to user friendliness, we chose to apply this model. Dynamic modeling can complement the indicator approach to sustainability 
and resilience assessment. While the story of Phnom Penh and its natural wetland treatment is a compelling one and important to discuss, the waterscape of the city can be seen in various, but similar, configurations throughout tropical Asia. The intent of this paper is less about the specifics of PCSWMM modeling per se, and more about taking some preliminary steps towards establishing modeling practices for urban communities in Cambodia (and other cities in Southeast Asia) which can be used and understood by the engineering community, the social science community, and public stakeholders (i.e. the multidisciplinary, interdisciplinary transdisciplinary model). When assessing urban water system sustainability, of course, it is important to consider the three pillars of environment, economy and society. However, both economic and social data with respect to water utilization and resources are limited in Cambodia and it was beyond the scope of this study to collect such data. Recognizing such a limitation, this paper focuses principally on the environmental pillar of sustainability. Ultimately, it would be useful to develop a decision support system or framework to help planners and engineers in this region assess sustainable urban water resource development (e.g. de Kok et al. 2009; Pearson et al. 2010).

\section{Study Area}

Phnom Penh, with a population of 1.5 million (2009), is serviced by a combined sewer system and flow is pumped to naturally occurring wetlands for treatment before it discharges to the Mekong River system (Visoth et al. 2010). A wetland system potentially can provide effective wastewater treatment as well as environmental and economic benefits that include reduced energy use, reduced use of chemicals, no fixed (or sunk) costs, and essentially no maintenance costs (Brix et al. 2007; Koottatep and Panuvatvanich 2010; Koottatep et al. 2005). Visoth et al. (2010) showed that Boeng Cheung Ek, the largest of Phnom Penh's naturally occurring treatment wetlands, was efficient in treating the city's waste. Because it was possible to build on previous water quality and quantity studies for the drainage system and wetland (e.g. Chea et al. 2010; Irvine et al. 2008; Marcussen et al. 2009; Ngoen-Klan et al. 2010; Sothea et al. 2010; Sovann et al. 2015; Takeuchi et al. 2005; Visoth et al. 2010), the focus of the work reported here also is the Boeng Cheung Ek wetland and contributing sewershed.

Phnom Penh's combined sewer system consists of a network of underground concrete and PVC sewer pipes that lead to open interceptor channels (e.g. Trabek and Meanchey channels, Figures 1 and 2). There is no wastewater treatment plant, so approximately $10 \%$ of the city's effluent flows directly into the Mekong River without any treatment. The remaining $90 \%$ is loaded into naturally occurring wetlands around the city for treatment. The surface area of the Boeng Cheung Ek wetland varies between $13 \mathrm{~km}^{2}$ in the dry season and $20 \mathrm{~km}^{2}$ in the rainy season.

Flow from the Trabek and Meanchey interceptor channels is pumped into Boeng Cheung Ek at the Trabek and Tumpun pump stations (Figure 3). The Trabek station, which drains the

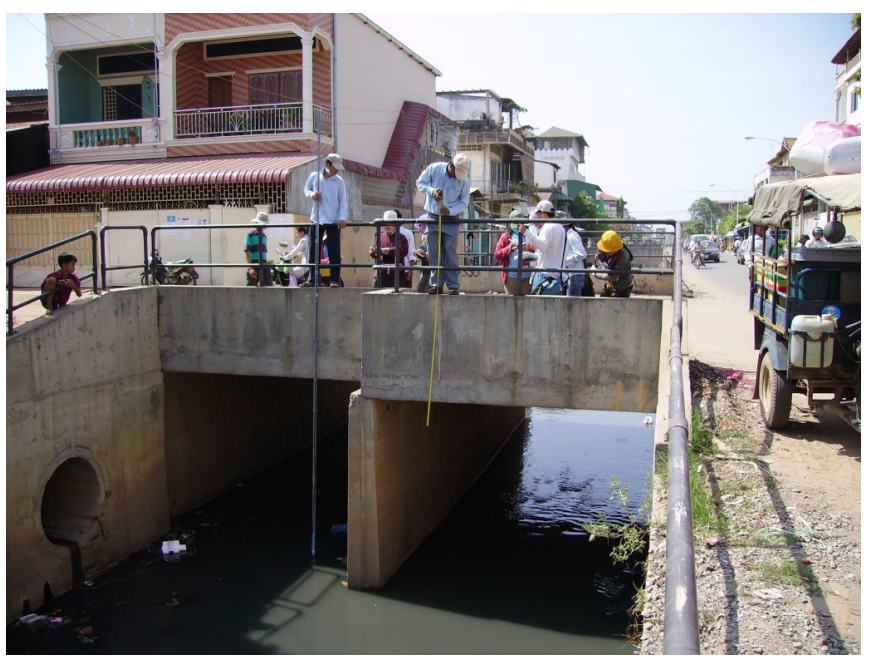

Figure 1 Sampling on the Trabek open interceptor sewer channel; an example of the underground pipe system discharging to the open channel can be seen lower left.

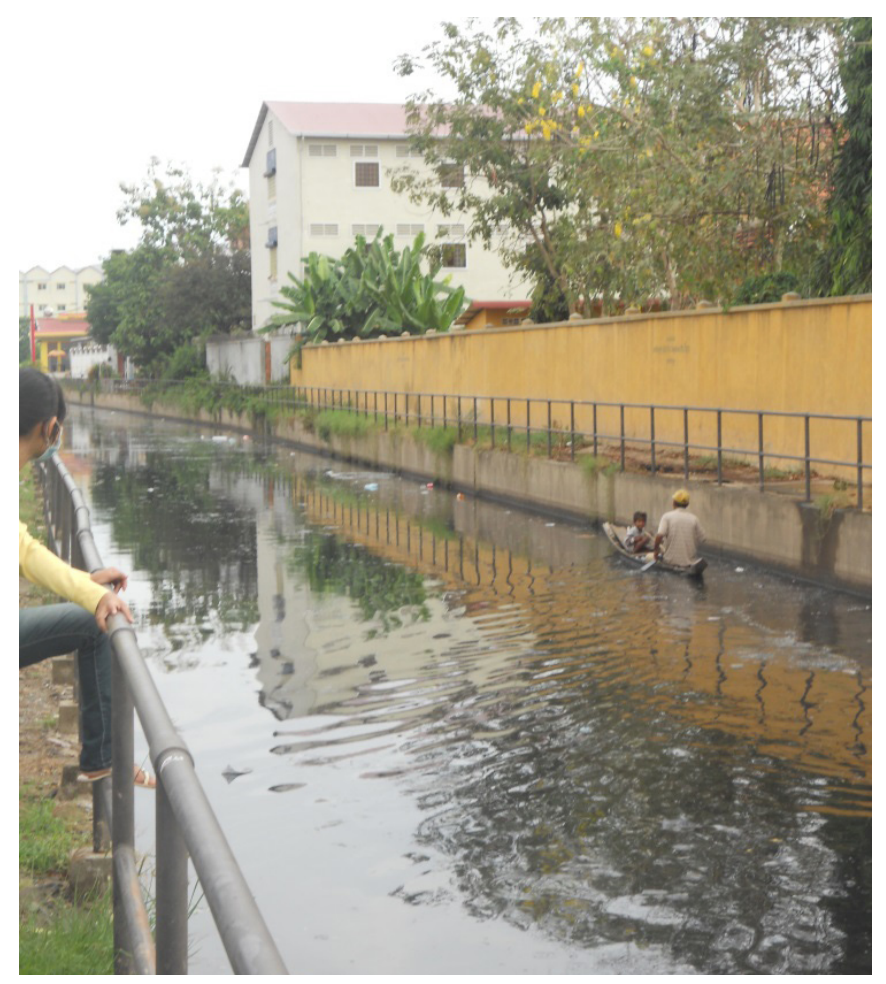

Figure 2 Trabek open interceptor sewer near the Trabek pump station.

Trabek sewershed, has eight pumps, each with a capacity of $1 \mathrm{~m}^{3} / \mathrm{s}$, while the Tumpun station, which drains the Meanchey sewershed, has five pumps, each with a capacity of $3 \mathrm{~m}^{3} / \mathrm{s}$. Discussions with the pump operators at the Tumpun station indicated that even during the largest storms historically only four pumps are run at a time for a total operational capacity of $12 \mathrm{~m}^{3} / \mathrm{s}$. In this study the base-of-comparison pumping rules for modeling purposes were therefore set to a maximum of $12 \mathrm{~m}^{3} / \mathrm{s}$. 


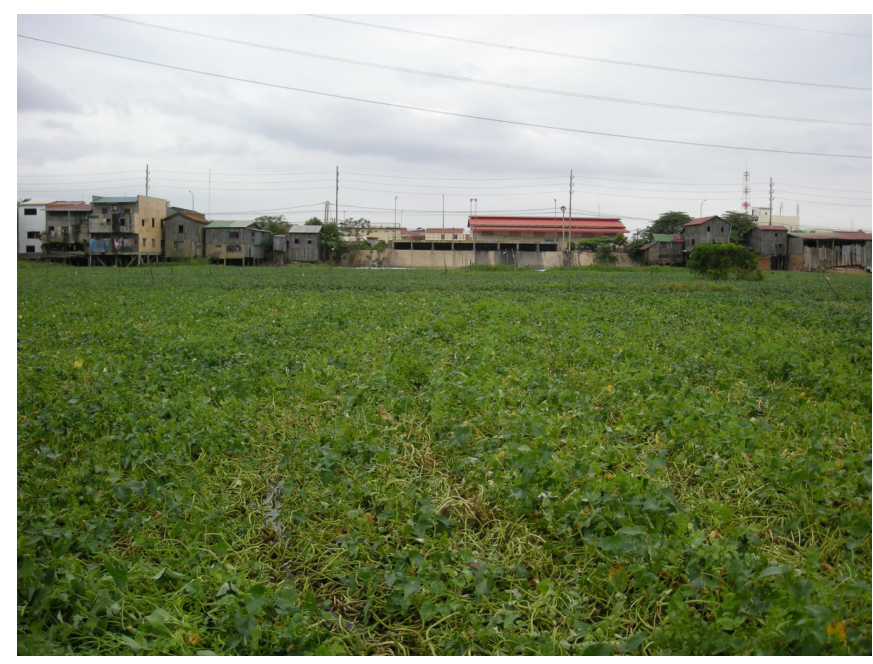

Figure 3 Trabek pump station (red roof, center of the picture) discharging wastewater to the Boeng Cheung Ek wetland, with fields of morning glory, foreground.

Boeng Cheung Ek has an extensive peri-urban community that uses the wetland for fishing and cultivating crops (Chea et al. 2010). In this sense, Boeng Cheung Ek shares similarities with the East Kolkata treatment wetlands of India (Ghosh 1999; 2014). Moeng (2004) reported that people living around the Boeng Trabek area (a smaller wetland connected to Boeng Cheung Ek) earned \$27.50/day, USD, from vegetable cropping in 2002. He also reported there were 294 farmers who harvested up to $26 \mathrm{t} / \mathrm{d}$ vegetables on the $1.23 \mathrm{~km}^{2}$ land area around Boeng Trabek, Boeng Cheung Ek and Boeng Tumpun wetlands. Unfortunately, there is no more recent demographic data available for Boeng Cheung Ek, but it has been the authors' qualitative observation that morning glory cropping, in particular, has expanded over the past decade.

\section{PCSWMM Model Application}

The entire south Phnom Penh sewer, pump and wetland system was seamlessly modeled with PCSWMM by Sovann et al. (2015), based on earlier work by Visoth et al. (2010) and Sothea et al. (2010). The calibrated PCSWMM model set up (Figure 4) reported by Sovann et al. (2015) was used as the base-of-comparison scenario for the work reported herein. Briefly, the study area (southern half of Phnom Penh, $25.83 \mathrm{~km}^{2}$ ) was divided into 55 subcatchments for modeling purposes (Figure 4). Subcatchment, sewer pipe and interceptor characteristics were determined through a combination of field measurement, lkonos satellite images ( $1 \mathrm{~m}$ resolution, taken in 2005) and internal reports, design drawings, maps, and discussions with the Municipality of Phnom Penh and Department of Public Works and Transportation (in Khmer), and JICA (1999; 2001; 2006). PCSWMM routing calculations, using a dynamic wave approach, were done at a $1 \mathrm{~s}$ time interval, with output reporting done every $10 \mathrm{~min}$ as well as averaging over the entire simulation period.

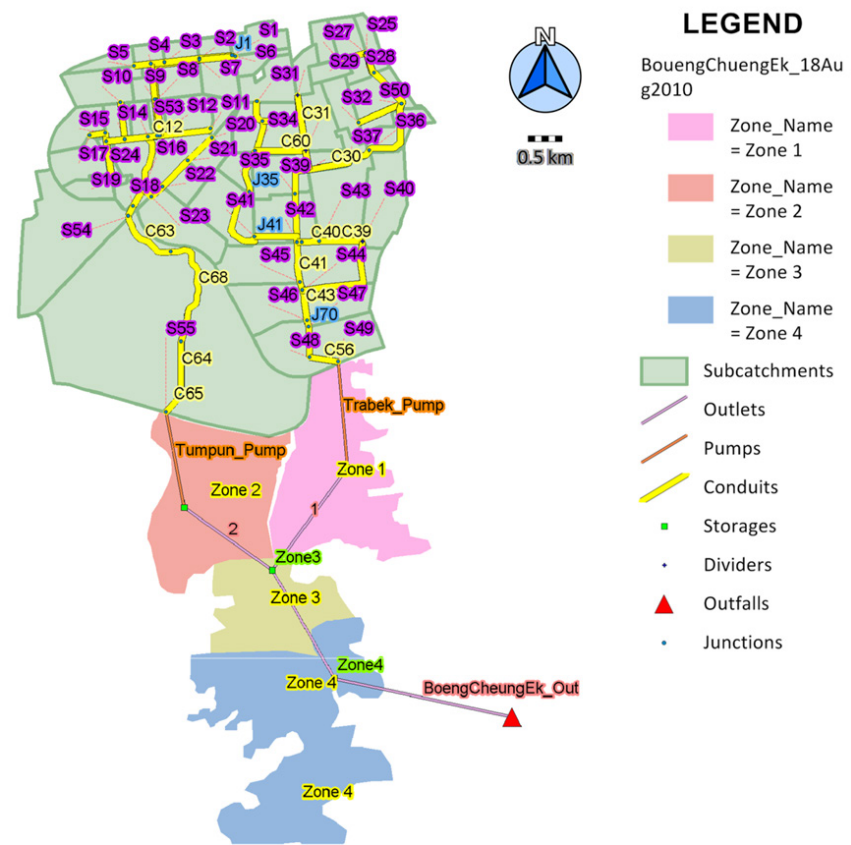

Figure 4 PCSWMM model schematic for south Phnom Penh, showing modeled sewer pipes (conduits), pump stations, and Boeng Cheung Ek wetland; for modeling purposes Boeng Cheung Ek was divided into four zones.

Data for model calibration in urban areas are quite limited for developing countries such as Cambodia. Dry weather flow was recorded at 5 min time steps using a Hach Sigma 910 areavelocity meter in the sewer along Mao Tse Tung Blvd (one of the larger underground sewer pipes that drain a mixed land use area) between 2011-03-25 and 2011-03-31. The daily dry weather pattern was distributed on a unit area basis for south Phnom Penh, as shown by Sovann et al. (2015). Calibration for storm events was based on observation of street surface flooding conducted by student teams in 2007 and 2008 (Visoth et al. 2010) and spot measurements of velocity in the interceptor sewers (Sovann et al. 2015; Visoth et al. 2010). Typically, modeled velocity was within $19 \%$ of measured velocity.

The wetland was divided into four zones for modeling purposes. Zones 1 and 2 directly receive the wastewater pumped through the Trabek and Tumpun pump stations. Zone 3 represents the narrower middle part of the wetland, while zone 4 includes the outlet towards the Bassac River at Ta Khmao.

PCSWMM provides different options to handle pollutant removal (treatment) within a wetland or detention pond and these can be programmed through the Treatment Editor. In general, a change in pollutant concentration $(\Delta C)$ during any time step $(\Delta t)$ can be represented as:

$$
\Delta C=C_{t} \cdot \sum f_{i} u_{i} \cdot \frac{\Delta t}{d}
$$

where: 
$C_{t}=$ concentration at time $t$, and

$f_{i}=$ fraction of pollutant with settling velocity $u_{i}$.

Here it is assumed pollutants would behave as a particle, which is appropriate for pollutants that tend to be particle-bound. However, since settling velocity frequently is not known, Equation 1 can be expressed as:

$$
\frac{\partial C t}{\partial t}=-\frac{k}{d} C_{t}
$$

where $k$ can be considered a representative settling velocity. Finally, then, by integrating between times $t$ and $t+\Delta t$, and assuming a residual concentration $C^{*}$ remaining in the water column, we get:

$$
C_{t+\Delta t}=C^{*}+\left(C_{t}-C^{*}\right) e^{-\left(\frac{k}{d}\right) \cdot \Delta t}
$$

Alternatively, treatment can be expressed as an empirical function of the pollutant concentration entering the pond or as a removal fraction (sometimes called a potency factor) of another pollutant. The empirical function may include one or more process variables (e.g. flow rate into the pond, depth of water above the pond bottom, surface area of the pond, hydraulic residence time, and routing time step). The empirical function approach provides the option, for example, of representing BOD through a first order decay expression of hydraulic residence time. For simplicity in this study, the removal fraction option was used to model pollutant treatment for each zone and the model was calibrated against the mean contaminant concentrations measured for each of the four zones in 2011 (Sovann et al. 2015).

\subsection{Base-of-Comparison Scenario}

Two important water resource issues have emerged in Phnom Penh as the city has begun to redevelop after the Khmer Rouge period: water quality associated with waste discharge; and localized urban flooding due to heavy rainfall and poorly maintained drainage systems (e.g. Chakrya and Yeap 2012; Irvine et al. 2006; Reaksmey 2012; Schneider 2011; Sina and Chen 2012; Sophakchakrya 2010). Studies of Boeng Cheung Ek's treatment efficiency showed that the wetland reduced $E$. coli levels by between $99 \%$ and $99.97 \%$; detergents by around $86 \%$; total phosphorus by between $31 \%$ and $71 \%$; and total nitrogen by $\leq 71 \%$ (Sovann et al. 2015; Visoth et al. 2010), which are quite remarkable results. Vuong et al. (2007) similarly noted that the wetland was effective in reducing thermotolerant coliforms between inlet and outlet.

However, a smaller treatment wetland in the northern part of the city (Boeng Kak) is being entirely filled in for urban development (Reaksmey 2012) and parts of Boeng Cheung Ek are starting to be filled in, with plans for more infill as the construction of Hun Sen Blvd that will connect Phnom Penh with Ta Khmao is underway. Increased flooding in the Boeng Kak area attributed to the infilling already has received media attention (Sina and Chen 2012).

The Boeng Cheung Ek configuration and bathymetry per the survey of March, 2011 (dry season) and August, 2011 (rainy season), as reported by Sovann et al. (2015), were used for the base-of-comparison modeling in this paper. Rainfall used for all model runs was taken from a tipping bucket rain gauge installed in the south-central part of the study area. The recorded rainfall data for the period 2011-05-10 to 2011-07-01 were binned into 10 min time steps to drive the PCSWMM model. We recognize that the simulation time is relatively short when extrapolating to a longer planning horizon, but as noted above long term data are not available in Cambodia. For this type of preliminary investigation, the short simulation timeframe is adequate.

\subsection{Boeng Cheung Ek Infilling Scenario}

Two scenarios were considered with respect to the infilling of Boeng Cheung Ek and wastewater treatment. The first scenario considered a possible reduced wetland size related to the construction of Hun Sen Blvd. The second scenario considered a total infill and the associated costs of alternative treatment using an activated sludge approach. Activated sludge was chosen as the alternative treatment approach because this treatment technology is commonly employed in North America and also in Thailand, particularly Bangkok (Liu et al. 2012; Noophan et al. 2009; Visvanathan 2011). Cost and energy data were therefore available for planning level calculations. Given the wetland infilling that currently is being done to construct Hun Sen Blvd, PCSWMM was used to examine possible impacts on treatment efficacy. Based on preliminary design reports (http://www.phnompenh.gov. kh/news-samdech-hun-sen-blvd-a-new-blood-vessel-for-southern-part-of-phnom-penh-851.html) Hun Sen Blvd will be $30 \mathrm{~m}$ wide and approximately $5900 \mathrm{~m}$ long. Traditionally in Cambodia houses and commercial structures have been built alongside roadways, so we assumed an additional $30 \mathrm{~m}$ would be infilled on either side of the boulevard for the entire length. This produced an infill area of $531000 \mathrm{~m}^{2}$ that was distributed equally across zones 1, 3 and 4 in the model (i.e. $177000 \mathrm{~m}^{2}$ wetland infilled in each of the three zones). Based on currently observed patterns of infill and the likelihood that additional infill would occur where Hun Sen Blvd branched into the wetland in Phnom Penh and out of the wetland near Ta Khmao, it was assumed an additional $20 \%$ of dry weather wetland area would be infilled in zones, 1, 2 and 4 .

The costs for construction and maintenance of two activated sludge plants were calculated from the data reported by Singhirunnusom and Stenstrom (2010) for Thailand. The dry weather (sanitary) flow for the entire study area was determined to be $52704 \mathrm{~m}^{3} / \mathrm{d}$ based on the monitoring reported by Sovann et al. (2015) and using a safety factor of $10 \%$, it was assumed $58500 \mathrm{~m}^{3} / \mathrm{d}$ of flow would be treated. Here we assumed only dry weather sanitary flow, is treated.

\subsection{Additional Pumping Capacity Scenarios to Reduce Surface Flooding}

Molyvann (2003) noted that Phnom Penh's pumping stations were neither numerous enough nor powerful enough to adequately fulfill their pumping functions. Two scenarios were 
considered with respect to increased pumping capacity at the existing Trabek and Tumpun pump stations that could be implemented to reduce the problem of surface flooding. The first scenario simply doubled the pump capacity at all forebay water levels over the operating range, to a maximum of $16 \mathrm{~m}^{3} / \mathrm{s}$ at the Trabek station and $24 \mathrm{~m}^{3} / \mathrm{s}$ at the Tumpun pump station. The second scenario maintained current pump capacity at the lower depths of flow, but as the storm progressed, the pump capacity was increased by up to triple the current capacity, to a maximum of $24 \mathrm{~m}^{3} / \mathrm{s}$ at the Trabek station and $36 \mathrm{~m}^{3} / \mathrm{s}$ at the Tumpum station.

\section{Results and Discussion}

\subsection{Rainfall Events}

As noted, the rainfall data for the period 2011-05-02 to 2011-07-01 were used as input to PCSWMM. This period represents the early rainy season in Phnom Penh, which is a time when flow in Boeng Cheung Ek is not yet influenced by a freshwater pulse entering from the Bassac River at the outlet of the wetland. A total of $362 \mathrm{~mm}$ rainfall was recorded for the modeled period, with two events having peak rainfall intensities of $48 \mathrm{~mm} / \mathrm{h}$.

\subsection{Boeng Cheung Ek Infilling}

Infill assumed for the wetland under the first scenario was $2.87 \mathrm{~km}^{2}$, which represents $22 \%$ of the $13 \mathrm{~km}^{2}$ dry weather area or $14 \%$ of the $20 \mathrm{~km}^{2}$ wet weather area. Results of the modeled base-of-comparison run and infill scenarios for water quality in zone 4, the outlet of the wetland, are shown in Table 1. To allow for model start-up in representing the large treatment wetland, the data in Table 1 represent the period 2011-05-15 to 2011-07-01 rather than from 2011-05-02. Not surprisingly, with infilling the modeled water depth in zone 4 of the wetland was greater (averaging $2.84 \mathrm{~m}$ ) than under the base-of-comparison (averaging $2.64 \mathrm{~m}$ ). To be conservative and using maximum concentration as an indicator, Table 1 shows that the modeled water quality under the infill scenario was poorer for all parameters except total phos- phorus. The water quality routing continuity errors (based on simple mass balance of a contaminant's initial storage, inputs to and outputs from the system) for PCSWMM were 4\%, 14\%, 3.9\% and $5.1 \%$ for detergents, E. coli, total phosphorus and total nitrogen respectively. The percentage increases in the maximum concentrations of $E$. coli, detergents and total nitrogen were greater than the routing continuity errors and it might therefore be expected that the infilling as outlined in this scenario could have a negative impact on effluent quality going to the Mekong-Bassac River system with respect to these parameters. It should be noted, however, that even with the infilling, detergents levels were below Cambodian water quality guidelines and the $E$. coli levels remained just below $\mathrm{WHO}$ guidelines for irrigation water used for vegetables eaten raw (1000 cfu/100 mL), or for that matter, secondary contact guidelines used in Canada (also $1000 \mathrm{cfu} / 100 \mathrm{~mL}$, Health Canada 2012). Wastewater quality data for Phnom Penh reported by various other studies are summarized in Table 2, for comparison purposes. Although there is some variability in the reported wastewater quality, the wetland appears capable of effective treatment.

Table 1 Water quality results for Boeng Cheung Ek Zone 4, current conditions (base-of-comparison) and infilling scenario.

\begin{tabular}{lcccccccc}
\hline & \multicolumn{3}{c}{ Basis-of-Comparison } & \multicolumn{4}{c}{ Wetland Infilling } \\
& Mean & S.D. & Min. & Max. & Mean & S.D. & Min. & Max. \\
\hline Detergents, $\mathrm{mg} / \mathrm{L}$ & 0.25 & 0.01 & 0.23 & 0.28 & 0.26 & 0.02 & 0.24 & 0.31 \\
E. coli, cfu/100 mL & 50 & 122 & 2.4 & 689 & 66 & 158 & 24 & 928 \\
Total Phosphorus, $\mathrm{mg} / \mathrm{L}$ & 4.7 & 0.46 & 3.4 & 5.1 & 4.9 & 0.31 & 3.9 & 5.1 \\
Total Nitrogen, $\mathrm{mg} / \mathrm{L}$ & 7.3 & 0.85 & 6.2 & 9.8 & 7.3 & 1.1 & 6 & 10.7 \\
\hline
\end{tabular}

Note: All values represent the mean of the modeled period, 2011-05-15 to 2011-07-01.

Should Boeng Cheung Ek be filled in entirely, one possi-

ble option for treatment would be construction of a traditional activated sludge plant, as is frequently used in neighbouring Thailand, for example (Noophan et al. 2009). While this technology is well proven and reliable, there are some issues of economic and environmental cost that should be considered in comparison to the current naturally occurring wetlands treatment. For example, Liu et al. (2012) noted that energy demand varies considerably by technology and the size of treatment plant, and in developed countries electricity may represent $5 \%$ to $30 \%$ of total operating

Table 2 Wastewater quality, Phnom Penh.

\begin{tabular}{|c|c|c|c|c|c|c|c|c|}
\hline & \multicolumn{2}{|c|}{ Takeuchi et al. 2005} & \multirow[t]{2}{*}{$\begin{array}{c}\text { Trabek Pump Station, } \\
2007 \text { to } 2008^{3}\end{array}$} & \multirow[t]{2}{*}{$\begin{array}{l}\text { Tumpun Pump Station, } \\
2007 \text { to } 2008^{3}\end{array}$} & \multicolumn{2}{|c|}{ Trabek Pump Station, 2011} & \multicolumn{2}{|c|}{ Tumpun Pump Station, 2011} \\
\hline & Dry Season ${ }^{1}$ & Rainy Season ${ }^{2}$ & & & Dry Season ${ }^{4}$ & Rainy Season ${ }^{5}$ & Dry Season ${ }^{4}$ & Rainy Season ${ }^{5}$ \\
\hline Detergents, mg/L & 8.2 & 2.0 & 12.7 & 11 & 2.5 & 7.5 & 7.5 & 5 \\
\hline E. coli, cfu x $10^{6} / 100 \mathrm{~mL}$ & & & 5.5 & 3.8 & 0.4 & 1 & 3.98 & 2.28 \\
\hline Total Phosphorus, mg/L & 5.6 & 2.0 & 5.4 & 4.6 & 14 & 9.6 & 10.6 & 9.2 \\
\hline Total Nitrogen, mg/L & 41 & 18 & & & 45 & 33 & 54 & 31 \\
\hline
\end{tabular}

'Mean of 15 sewer sample sites, collected 1997-12-23 to 1997-12-27;

2Mean of 10 sewer sample sites, collected 1998-09-27 to 1998-09-30;

${ }^{3}$ Mean of 14 dry weather sample dates, as reported by Visoth et al. (2010);

${ }^{4}$ Sample collected 2011-03-27;

5Sample collected 2011-08-02 
costs, rising to $40 \%$ in developing countries. Visvanathan (2011) indicated that electricity is $50 \%$ of the operating costs for plants in Bangkok. Liu et al. (2012) also reported that in the United States electric consumption in large activated sludge plants (>380 $000 \mathrm{~m}^{3} / \mathrm{d}$ ) is on the order of $0.272 \mathrm{kWh} / \mathrm{m}^{3}$ wastewater treated. This likely would underestimate electric consumption for a plant in Cambodia but recognizing this shortcoming and considering treatment exclusively of sanitary waste at a rate of 58500 $\mathrm{m}^{3} / \mathrm{d}$ (as noted previously), $15912 \mathrm{kWh} / \mathrm{d}$ electricity would be consumed under this scenario. The Cambodian government sells electricity generated by hydropower at a rate of approximately $\$ 0.2 / \mathrm{kWh}$ to $\$ 0.25 / \mathrm{kWh}$ (2009 USD) and should diesel power be the source of electricity, the rate climbs to $\$ 0.4 / \mathrm{kWh}$ to $\$ 0.7 / \mathrm{kWh}$ (2009 USD, Sophal 2009). This translates to an annual operating cost of $\$ 1$ million to 1.3 million (2009 USD) for hydro sourced electricity and \$2.1 million to $\$ 3.7$ million (2009 USD) for diesel sourced electricity. Diesel power would also increase greenhouse gas emissions.

Singhirunnusom and Stenstrom (2010) reported construction and operating costs for activated sludge plants in Thailand and identified the following relationships:

$C=0.0031 Q^{0.881} ; \quad r^{2}=0.979$

and

$$
O \mho M=0.0529+1.31 \times 10^{-5} F ; \quad r^{2}=0.996
$$

where:

$$
\begin{aligned}
C= & \text { construction cost in millions of USD, } \\
Q= & \text { design capacity in } \mathrm{m}^{3} / \mathrm{d}, \\
O \& M= & \text { annual operation and maintenance cost in } \\
& \text { millions of USD, and }
\end{aligned}
$$$$
F=\text { actual flow in } \mathrm{m}^{3} / \mathrm{d} \text {. }
$$

Here, $Q$ and $F$ are considered equivalent and take a value of $58500 \mathrm{~m}^{3} / \mathrm{d}$. Based on Equations 4 and 5, construction cost for an activated sludge plant in Phnom Penh (that would treat all wastewater from the Trabek and Meanchey sewersheds, combined) would be on the order of $\$ 49.1$ million USD and annual O\&M would be $\$ 0.82$ million USD. This estimate of $O \& M$ is less than the electricity costs estimated using simple energy consumption as noted above (\$1 to $\$ 3.7$ million USD per year), but electricity costs in Thailand may be about half the rate used here for Cambodian hydropower-sourced electricity (http://www.boi.go.th/index. php?page =utility costs\&language=en). Therefore, it might be expected that Equation 5 would provide a lower O\&M estimate. While these cost calculations are useful to explore, ultimately the municipality has no plans nor budget to construct such a plant (http://www.cambodiadaily.com/archives/as-phnom-penhgrows-so-does-its-sewage-problem-23419/).

\subsection{Localized Surface Flooding Reduction through Increased Pumping Capacity}

Table 3 summarizes model results for localized surface flooding under base-of-comparison conditions and the two different scenarios of increased pumping. While both pumping scenarios decreased the surface flooding volume, mean and standard deviation of surface flood time, Table 3 shows that surface flooding still would occur. Current data on the cost of pump operation are not readily available, but in its basic design study JICA estimated the cost of the Tumpun pump station upgrade to current conditions would be $\$ 1.2$ million USD and the annual O\&M would be $\$ 221000$ USD (JICA 2001). These costs could be used as a starting reference for the increased pumping capacity. PCSWMM results also indicate that certain areas experience relatively greater flooding problems than others as a result of system constraints that cannot be addressed by increased pumping. Specifically, areas in subcatchments S3, S17, S42, S46 and S55 remain at risk of flooding (Figure 3, above).

One option to reduce surface flooding, in addition to increasing pump capacity, is the construction of underground holding tanks. This approach, recently completed in the northern section of the city at a design cost of $\$ 26.7$ million USD (JICA 2006), could be evaluated for the Trabek and Meanchey sewersheds using PCSWMM. PCSWMM includes system design tools to appropriately size holding tanks. Alternatively, low impact development (LID) designs could be explored using PCSWMM. Globally, LID technologies including green roofs, bioretention cells, permeable pavement, rain barrels or cisterns, and grassed swales increasingly are being implemented (Ahiablame et al. 2012; Shamsi 2010), and in Southeast Asia Singapore has aggressively implemented LID designs (Irvine et al. 2014). LID technologies most certainly are consistent with eco-city planning philosophy.

\begin{tabular}{|c|c|c|c|}
\hline Scenario & Mean Number of Hours Flooded for Modeled Period ${ }^{1}$ & $\begin{array}{c}\text { Standard Deviation of Hours Flooded for Modeled } \\
\text { Period }\end{array}$ & Total Volume of Flooding for Modeled Period, $\times 10^{6} \mathrm{~L}$ \\
\hline Base-of-Comparison & 3.6 & 4.7 & 2052 \\
\hline Double Pump Rate & 3.2 & 4.2 & 1341 \\
\hline Triple Pump Rate at Greater Depths & 3.1 & 4.1 & 1136 \\
\hline
\end{tabular}
Modeling efforts that assess the effects of these technologies increasingly are available, to the point that they are now explicitly

Table 3 Flooding results for all modeled subcatchments, combined, current conditions (base-of-comparison) and increased pumping scenarios.

'Modeled period: 2011-05-02 to 2011-07-01. 
included as an option in the Stormwater Management Model (Rossman 2010).

However, some important gaps in our understanding of LID operations remain, as, for example, there seems to be very little empirical data at a large sewershed scale, across multiple storms and seasons, to confirm performance of the technologies and models (Irvine 2013). Modeling efforts to date seem to suggest that LID technologies are less helpful in managing larger events (Gill et al. 2007; Holman-Dodds et al. 2003) , although an unpublished report by Drexel University for a test area in Cambria Heights, New York City, showed that LID technology performed exceedingly well in controlling runoff from superstorm Sandy and hurricane Irene. Hopefully, the data gaps are starting to change with projects described, for example, by Pitt and Voorhees (2011), although more work in tropical environments is needed.

\section{The Way Forward-Urban Planning and the Wetlands of Phnom Penh}

Renowned Cambodian architect and urban planner, Vann Molyvann, in his book Modern Khmer Cities, provides some important observations on the methods and historical importance of water management in Cambodia, as well as some recommendations for future urban development. He notes that in the 1950s and 1960s large areas of Phnom Penh were turned into landscaped gardens, surrounded by reservoirs. The original outward expansion of the city was accompanied by well planned water management schemes that incorporated the traditional prek and beng (boeng) design to collect and drain the water. Yet he argues most prek and beng have been filled in, "dramatically reducing the places in the city where water can run off or be stored." The management of urban form in Phnom Penh will signal the path for development in other urban areas of Cambodia, but Molyvann is concerned that Phnom Penh is not following the best path. The city has no official master plan, yet new (and often controversial) construction abounds, making Phnom Penh one of the most expensive property markets in Southeast Asia (Nam 2011). Unfortunately, this development often follows the pave all approach, which takes it in the opposite direction of eco-city planning.

By contrast, during the 1980s the West Bengal government in India established development control measures to ensure the preservation of the $125 \mathrm{~km}^{2}$ East Kolkata wetland that both treats urban wastewater and hosts peri-urban fisheries crops and rice paddies (Ghosh 1999; 2014). Health issues related to use of wastewater in agriculture and aquaculture practices are a concern and need to be managed, but globally there is a long history of wastewater reuse and studies indicate there are economic and environmental benefits when practised appropriately (Drechsel and Seidu 2011; Heinz et al. 2011; Jimenez and Asano 2008; Miller 2006; Murray et al. 2011; Weldesilassie et al. 2011; Wichelns et al. 2011 ). Health risks related to use of Boeng Cheung Ek have been examined elsewhere (Chea et al. 2010; Marcussen et al. 2009; Ngoen-Klan et al. 2010) and currently the primary risk seems to be from biological (rather than chemical) vectors, which can be more easily managed through public education. Preservation of Phnom Penh's remaining wetlands, as was done in West Bengal, would be prudent, cost effective, and consistent with both ecocity planning principles and the historical water management practices of Cambodia.

\section{The Way Forward-Need for a Decision Support System (DSS)}

Silva-Hidalgo et al. (2009) examined the issue of modeling for Integrated Water Resources Management (IWRM) and concluded that while mathematical models can be valuable tools, in addition to hydrology, new models needed to be developed to include social, economic, legal and environmental considerations. Too often, it was felt, models provided a theoretical rather than practical solution for planning and frequently models were not accepted or understood by non-experts. Serrat-Capdevila et al. (2011) stated that "In general, scientists, academicians and some practitioners are convinced that numerical models are indeed a good tool to support decision making, but the reality is that the adoption of modeling tools by policy and decision makers is not standard practice." Furthermore, Smith Korfmacher (2001), in discussing arguments against public participation in watershed modeling, cited the general lack of expertise in such applications. While the indicator approach is attractive for its apparent simplicity and ease of understanding, and the capacity to facilitate intercity comparisons of sustainability, development scenarios and design plans for implementation cannot be done with this approach. In fact, the use of the indicator approach and more detailed dynamic modeling to assess and manage urban water resources may not be mutually exclusive, but rather suggests the need for a DSS. Abundant examples of a DSS for larger watersheds exist (e.g. Choi et al. 2005; de Kok et al. 2009; Rodgers et al. 2007; Rutledge et al. 2008) but it is less clear how a DSS might evolve for smaller urban sewersheds, particularly in developing countries of Southeast Asia. There does seem to be consensus that for a DSS to be successfully implemented, all stakeholders need to participate in its development from the start (Rodgers et al. 2007; Roux et al. 2006; Serrat-Capdevila et al. 2011).

In this paper we have demonstrated that PCSWMM can be used to address practical planning questions that could be posed by technical staff and public alike. PCSWWM could form part of the core of a DSS for eco-city planning, but the DSS may in fact be more of a theoretical framework or formal set of planning steps, as opposed to explicitly linked software modules. This theoretical framework remains to be developed, but should incorporate aspects of adaptive management and social learning, as discussed by Pearson et al. (2010).

\section{Conclusion}

PCSWMM was applied to evaluate wastewater treatment and surface flooding scenarios for Phnom Penh, Cambodia. The model 
showed that treatment was negatively impacted but could still be effective under urban expansion scenarios that reduce the wetland area by up to $\sim 22 \%$. It is possible that wastewater treatment in a smaller wetland could be optimized by enhancing hydraulic retention and strategic plantings and such designs could be evaluated at a planning level using PCSWMM. The wastewater volume used in the modeling effort reflected current levels. With a growing population, more wastewater will be generated and such growth also could be explored using PCSWMM. The natural wetlands are consistent with eco-city philosophy and in addition to water quality services, provide ecosystem services including enhanced biodiversity and floodwater storage, food security through peri-urban agriculture and aquaculture, and a cultural touchstone for the peri-urban community. This type of economic valuation is challenging, can be controversial, and requires considerable effort (Kenter et al. 2011; Norgaard 2010; Pattanayak 2004; Turner et al. 2011; Whittington 1998), which was beyond the scope of this project, but such valuation nonetheless should be considered as a next step in developing a wetlands management strategy.

Increased pump capacity at the existing stations was evaluated using PCSWMM as potentially the most expedient option to reduce localized surface flooding in the southern part of the city. While the increased pumping reduced duration and volume of surface flooding, there are sections of the city that still would experience flooding due to drainage system constraints. LID options to reduce surface flooding could be explored effectively using PCSWMM.

Scenarios assessed here are but one set of examples of a multitude of options that could be assessed using PCSWMM. Certainly it would be useful to examine a greater range of hydrometeorological conditions (e.g. rainy season vs dry season) and consider potential impacts due to climate change. We argue that by applying dynamic modeling tools when considering development scenarios, urban planners, engineers, scientists, social scientists, developers, and community stakeholders can collectively make more certain steps towards achieving a sustainable city. Work remains to develop a truly integrated, multidisciplinary decision support framework for urban water resources management.

\section{Acknowledgments}

This study was supported by a grant from the International Environmental Research Center (IERC), United Nations University (UNU) \& Gwangju Institute of Science and Technology (GIST). We are indebted to Visal YOEUNG, Vichet HANG, Naykim PHY, Bunratha LAO, Chandath HIM and Bandith SENG for their assistance in the field and laboratory. K. N. Irvine's participation was funded, in part, by a research grant from the Association of American Geographers and the work was completed while he was on sabbatical from Buffalo State, State University of New York. Thanks to the three anonymous reviewers whose comments served to strength- en the paper. Any shortcomings of the paper, of course, are the sole responsibility of the authors.

\section{References}

Ahiablame, L. M., B. A. Engel and I. Chaubey. 2012. “Effectiveness of Low Impact Development Practices: Literature Review and Suggestions for Future Research." Water, Air and Soil Pollution 223:4253-73.

Axelsson, R. 2010. "Integrative Research and Transdisciplinary Knowledge Production: A Review of Barriers and Bridges." Journal of Landscape Ecology 4 (2): 14-40.

Brix, H., H. H. Schierup and C. A. Arias. 2007. "Twenty Years Experience with Constructed Wetland Systems in Denmark-What Did We Learn?" Water Science and Technology $56(3): 63-8$.

Burch, S. 2010. “Transforming Barriers into Enablers of Action on Climate Change: Insights from Three Municipal Case Studies in British Columbia, Canada." Global Environmental Change 20:287-97.

Chakrya, K. S. and C. Yeap. 2012. “Storms Swamp Capital Streets in Drain Strain." Phnom Penh Post, 22 May.

Chaosakul, T., T. Koottatep and K. N. Irvine. 2013. "Low Impact Development Modeling to Assess Localized Flood Reduction in Thailand." Journal of Water Management Modeling R246-18. doi: 10.14796/JWMM.R246-18.

Chea, E., D. Va and K. Irvine. 2010. "Levels of Cr, Cu, And Zn in Food Stuffs From A Wastewater Treatment Wetland, Phnom Penh: A Preliminary Assessment Of Health Risks." Asian Journal of Water, Environment and Pollution 7 (3): 23-30.

Choi, J-Y, B. A. Engel, L. Theller and J. Harbor. 2005. “Utilizing WebBased GIS and SDSS for Hydrological Land Use Change Impact Assessment." Transactions of the ASAE 48 (2): 815-22.

Chow, M. F., Z. Yusop and M. E. Toriman. 2012. “Modelling Runoff Quantity and Quality in Tropical Urban Catchments using Storm Water Management Model. International Journal of Environmental Science and Technology 9:737-48.

Clark, W. C. and N. M. Dickson. 2003. "Sustainability Science: The Emerging Research Program." Proceedings of the National Academy of Sciences 100 (14): 8059-61.

Ciegis, R., J. Ramanauskiene and G. Startiene. 2009. “Theoretical Reasoning of the Use of Indicators and Indices for Sustainable Development Assessment." Engineering Economics 3:33-40.

de Kok, J-L., S. Kofalk, J. Berlekamp, B. Hahn and H. Wind. 2009. "From Design to Application of a Decision-Support System for Integrated River-Basin Management." Water Resources Management 23:1781-1811. 
Ding, Y., D. Tang, H. Dai and Y. Wei. 2014. "Human-Water Harmony Index: A New Approach to Assess the Human Water Relationship." Water Resources Management 28:1061-77.

Drechsel, P., and R. Seidu. 2011. “Cost-effectiveness of Options for Reducing Health Risks in Areas where Food Crops are Irrigated with Treated or Untreated wastewater." Water International 36 (4) 535-48.

Eriksen, S. H. and P. M. Kelly. 2007. “Developing Credible Vulnerability Indicators for Climate Adaptation Policy Assessment." Mitigation and Adaptation Strategies for Global Change 12:495-524.

Ghosh, D. 1999. "Water Utilization in East Calcutta Wetlands.” Urban Waste Expertise Program, Occasional Paper. Netherlands: Netherlands Development Assistance Program.

Ghosh, D. 2014. Ecosystem Management Towards Merging Theory and Practice. New Delhi: NIMBY Books.

Gill, S. E., J. F. Handle, A. R. Ennos and S. Pauleit. 2007. "Adapting Cities for Climate Change: The Role of the Green Infrastructure." Built Environment 33 (1): 115-33.

Health Canada. 2012. Guidelines for Canadian Recreational Water Quality, 3rd edn. Ottawa: Health Canada.

Heberlein, T. A. 1988. "Improving Interdisciplinary Research: Integrating the Social and Natural Sciences." Society and Natural Resources 1:5-16.

Heinz, I., M. Salgot and J. M-S. Dávila. 2011. “Evaluating the Costs and Benefits of Water Reuse and Exchange Projects Involving Cities and Farmers." Water International 36 (4) 455-66.

Holman-Dodds, J. K., A. A. Bradley and K. W. Potter. 2003. “Evaluation of Hydrologic Benefits of Infiltration Based Urban Storm Water Management." Journal of the American Water Resources Association 39 (1): 205-15.

Irvine, K. N. 2013. "Climate Change and Urban Hydrology: Research Needs in the Developed and Developing Worlds." Journal of Water Management Modeling R246-11. doi: 10.14796/JWMM.R246-11.

Irvine, K. N., L. H. C. Chua and H. S. Eikass. 2014. "The Four National Taps of Singapore: A Holistic Approach to Water Resources Management from Drainage to Drinking Water." Journal of Water Management Modeling C375. doi: 10.14796/JWMM.C375.

Irvine, K., M. Sampson, T. Visoth, M. Yim, K. Veasna, T. Koottatep and J. Rupp. 2008. "Spatial Patterns of E. Coli and Detergents in the Boeng Cheung Ek Treatment Wetland, Phnom Penh, Cambodia." In The 6th International Symposium on Southeast Asian Water Environment, 78-81. Bandung: SEAWE.

Irvine, K. N., T. Murphy, M. Sampson, V. Dany, S. J. Vermette and T. Tang. 2006. "An Overview of Water Quality Issues in Cambodia." Journal of Water Management Modeling R225-02. doi: 10.14796/JWMM.R225-02.
Jackson, L. E. 2003. “The Relationship of Urban Design to Human Health and Condition." Landscape and Urban Planning 64:191-200.

JICA. 1999. The study on drainage improvement and flood control in the municipality of Phnom Penh, final report. Japan: JICA.

JICA. 2001. Basic design study report on the project for flood protection and drainage improvement in the municipality of Phnom Penh in the Kingdom of Cambodia. Japan: JICA.

JICA. 2006. Basic design study report on the project for flood protection and drainage improvement in the Municipality of Phnom Penh (Phase II) in the Kingdom of Cambodia. Japan: JICA.

Jimenez, B. and T. Asano. 2008. Water Reclamation and Reuse Around the World. In Water Reuse. An International Survey of Current Practice Issues and Needs, edited by B. Jiménez and T. Asano, 3-26. London: IWA.

Johnston, R. and M. Kummu. 2012. "Water Resource Models in the Mekong Basin: A Review." Water Resources Management 26:429-55.

Joss, S. 2010. “Eco-Cities-A Global Survey 2009." WIT Transactions on Ecology and the Environment 229:239-50.

Kenter, J. O., T. Hyde, M. Christie and I. Fazey. 2011. “The Importance of Deliberation in Valuing Ecosystem Services in Developing Countries-Evidence from the Solomon Islands." Global Environmental Change 21 (2): 505-21.

Kenworthy, J. R. 2006. “The Eco-City: Ten Key Transport and Planning Dimensions for Sustainable City Development." Environment and Urbanization 18:67-84.

Keskinen, M. 2006. “The Lake with Floating Villages: Socio-Economic Analysis of the Tonle Sap Lake." Water Resources Development 22 (3): 463-80.

Keskinen, M., J. Koponen, M. Kummu, J. Nikula, J. Sarkkula and O. Varis. 2005. "Integration of Socio-economic and Hydrological Data in the Tonle Sap Lake, Cambodia." In Proceedings of the 2005 International Conference on Simulation \& Modeling SimMod05. Bangkok: Asian Institute of Technology.

Koottatep, T. and A. Panuvatvanich. 2010. "Constructed Wetlands for Effective Wastewater Treatment." In Water Resources and Development in Southeast Asia, edited by K. Irvine, T. Murphy, V. Vanchan and S. Vermette, 179-92. Boston: Pearson Custom Publishing.

Koottatep, T., N. Surinkul, C. Polprasert, A. S. M. Kamal, D. Kone, A. Montangero, U. Heinss and M. Strauss. 2005. "Treatment of Septage in Constructed Wetlands in Tropical Climate: Lessons Learnt from Seven Years of Operation." Water Science and Technology 51:119-26.

Kummu, M., J. Sarkkula, J. Koponen and J. Nikula. 2006. “Ecosystem Management of the Tonle Sap Lake: An Integrated Modeling Approach." Water Resources Development 22 (3): 497-519. 
Liu, F., A. Ouedraogo, S. Manghee and A. Danilenko. 2012. A Primer on Energy Efficiency for Municipal Water and Wastewater Utilities. Report, Energy Sector Assistance Program, The World Bank. Washington, DC: World Bank.

Lowe. P. and J. Phillipson. 2009. "Barriers to Research Collaboration Across Disciplines: Scientific Paradigms and Institutional Practices." Environment and Planning A 41:1171-84.

Marcussen, H., A. Dalsgaard and P. E. Holm. 2009. "Element Concentrations in Water Spinach (Ipomoea aquatica Forsk.), Fish and Sediment from a Wetland Production System that Receives Wastewater from Phnom Penh, Cambodia." Journal of Environmental Science and Health Part A 44: 67-77.

Miller, G. W. 2006. “Integrated Concepts of Water Reuse: Managing Global Water Needs." Desalination 187:65-75.

Moeng, S. 2004. Avoiding Adverse Health Impacts from Contaminated Vegetables: Options for the Wetlands in Phnom Penh, Cambodia. Singapore: Economy and Environment Program for Southeast Asia. Research Report No. 2004-RRS.

Molyvann, V. 2003. Modern Khmer Cities. Phnom Penh: Reyum Publishing.

Mori, K. and A. Christodoulou. 2012. "Review of Sustainability Indices and Indicators: Towards a New City Sustainability Index (CSI)." Environmental Impact Assessment Review 32 (1): 94-106.

Murray, A., D. M. Gayathri and X. Chen. 2011. “Evolving Policies and the Roles of Public and Private Stakeholders in Wastewater and Faecal-sludge Management in India, China and Ghana." Water International 36 (4): 491-504.

Nam, S. 2011. "Phnom Penh: from the Politics of ruin to the Possibilities of Return." Traditional Dwelling and Settlements Review 23:55-68.

Ng, M. K. and P. Hills. 2003. "World Cities or Great Cities? A Comparative Study of Five Asian Metropolises." Cities 20 (3): 151-65.

Ngoen-Klan, R., S. Piangjai, P. Somwang, K. Moophayak, K. Sukontason, K. L. Sukontason, M. Sampson and K. Irvine. 2010. "Emerging Helminthes Infection in Snails and Cyprinoid Fish in Sewage Treatment Wetlands Waters in Cambodia." Asian Journal of Water, Environment and Pollution 7 (3): 1321.

Noophan, P., P. Paopuree, K. Kanlayaras, S. Sirivithayapakorn and S. Techkarnjanaruk. 2009. "Nitrogen Removal Efficiency at Centralized Domestic Wastewater Treatment Plants in Bangkok, Thailand." Environment Asia 2:30-5.

Norgaard, R. B. 2010. “Ecosystem Services: From Eye-Opening Metaphor to Complexity Blinder." Ecological Economics 69:1219-27.

Northridge, M. E., E. D. Sclar, and P. Biswas. 2003. “Sorting Out the Connections Between the Built Environment and Health: A Conceptual Framework for Navigating Pathways and Planning Healthy Cities." Journal of Urban Health 80 (4): 556-68.
Pattanayak, S. K. 2004. "Valuing Watershed Services: Concepts and Empirics from Southeast Asia." Agriculture, Ecosystems and Environment 104:171-84.

Pearson, L. J., A. C. Coggan, W. Proctor and T. F. Smith 2010. “A Sustainable Decision Support Framework for Urban Water Management." Water Resources Management 24:363-76.

Petit-Boix, A., D. Sanjuan-Delmais, C. M. Gasol, G. Villalba, M. E. Suarez-Ojeda, X. Gabarrell, A. Josa and J. Rieradevall. 2014. "Environmental Assessment of Sewer Construction in Small to Medium Sized Cities using Life Cycle Assessment." Water Resources Management 28:979-97.

Pitt R. and J. Voorhees. 2011. Modeling Green Infrastructure Components in a Combined Sewer Area. Journal of Water Management Modeling R241-08. doi: 10.14796/JWMM.R241-08.

Pruss-Ustun, A., J. Bartram, T. Clasen, J. M. Colford, O. Cumming et al. 2014. "Burden of Disease from Inadequate Water, Sanitation and Hygiene in Low- And Middle-Income Settings: A Retrospective Analysis of Data from 145 Countries." Tropical Medicine and International Health 19 (8): 894-905.

Ravetz, J. 2000. "Integrated Assessment for Sustainability Appraisal in Cities and Regions." Environmental Impact Assessment Review 20:31-64.

Reaksmey, H. 2012. "Questions Over Missing 10 Hectares of Lake." The Cambodia Daily, May 14.

Reed, M., S. Evan, D. G. Fraser and A. J. Dougill. 2006. "An Adaptive Learning Process for Developing and Applying Sustainability Indicators with Local Communities." Ecological Economics 59:406-18.

Roseland, M. 1997. “Dimensions of the Eco-City." Cities 14 (4): 197202.

Rodgers, C., N. van de Giesen, W. Laube, P. L. G. Vlek and E. Youkhana. 2007. "The GLOWA Volta Project: A Framework for Water Resources Decision-Making and Scientific Capacity Building in a Transnational West African Basin." Water Resources Management 21:295-313.

Rossman, L. A. 2010. "Modeling Low Impact Development Alternatives with SWMM." Journal of Water Management Modeling R236-11. doi: 10.14796/JWMM.R236-11.

Roughly, A. and D. Salt. 2005. "Introduction of Social Sciences in Australian Natural Resource Management Agencies." Journal of Research Practice 1(2). http://www.jrp.icaap.org/index.php/jrp/article/view/12/31. Accessed 6 December 2013

Roux, D. J., K. H. Rogers, H. C. Biggs, P. F. Ashton and A. Sergeant. 2006. "Bridging the Science-Management Divide: Moving from Unidirectional Knowledge Transfer to Knowledge Interfacing and Sharing." Ecology and Society 11 (1): 4.

Rutledge, D. T., M. Cameron, S. Elliott, T. Fenton et al. 2008. "Choosing Regional Futures: Challenges and Choices in 
Building Integrated Models to Support Long-Term Regional Planning In New Zealand." Regional Science Policy \& Practice 1 (1): 85-108.

Sahely, H. R., C. A. Kennedy and B. J. Adams. 2005. “Developing Sustainability Criteria for Urban Infrastructure Systems." Canadian Journal of Civil Engineering 32:72-85.

Schneider, H. 2011. “Development at the Expense of the Environment and the Poor: The Conflict for Boeng Kak Lake in Phnom Penh, Cambodia." Pacific News 36:4-10.

Schoot Uiterkamp, A. J. M. and C. Vlek. 2007. “Practices and Outcomes of Multidisciplinary Research for Environmental Sustainability." Journal of Social Issues 63 (1): 175-97.

Serrat-Capdevila, A., J. B. Valdes and H. V. Gupta. 2011. “Decision Support Systems in Water Resources Planning and Management: Stakeholder Participation and the Sustainable Path to Science-Based Decision-Making." Chap. 21 in Efficient Decision Support Systems-Practices and Challenges from Current to Future, edited by C. Jao. InTech. http://www. intechopen.com/books/efficient-decision-support-systems-practice-and-challenges-from-current-to-future/ decision-support-systems-in-water-resources-planning-and-management-stakeholder-participation-and-th doi: 10.5772/16897.

Shamsi, U. M. 2010. “Low impact Development for Stormwater Quantity and Quality." Journal of Water Management Modeling R236-13. doi: 10.14796/JWMM.R236-13.

Shen, L-Y., J. J. Ochoa, M. N. Shah and X. Zhang. 2011 “The Application of Urban Sustainability Indicators-A Comparison between Various Practices." Habitat International 35:17-29.

Shrestha, A., T. Chaosakul, D. P. M. P. Priyankara, L. H. Chuyen, S. S. Myat, N. K. Syne, K. N. Irvine, T. Koottatep and M. S. Babel. 2014. "Application of PCSWMM to Explore Possible Climate Change Impacts on Surface Flooding in a Peri-Urban Area Of Pathumthani, Thailand." Journal of Water Management Modeling C377. doi: 10.14796/JWMM.C377.

Silva-Hidalgo, H., I. R. Martin-Dominguez, M. T. Alarcon-Herrera and A. Granados-Olivas. 2009. "Mathematical Modeling for the Integrated Management of Water Resources in Hydrological Basins." Water Resources Management 23:721-30.

Sina T. and D.-H. Chen. 2012. "With Boeng Kak Lake Filled In, Predictions of Flooding Loom." The Cambodia Daily, May 11.

Singhirunnusorn, W. and M. K. Stenstrom. 2010. "A Critical Analysis of Economic Factors for Diverse Wastewater Treatment Processes: Case Studies in Thailand." Sustainable Environment Research 20 (4): 263-8.

Smith Korfmacher, K. 2001. "The Politics of Participation in Watershed Modeling." Environmental Management 27 (2): 161-76.

Sophakchakrya, K. 2010." Groups Slam ‘Deliberate' Flooding.” Phnom Penh Post, September 13.
Sothea, K., S. Chansopheaktra, K. Irvine and K. Duval. 2010. "Phnom Penh Sewer Modeling and Contaminant Load Estimates." Asian Journal of Water, Environment and Pollution 7 (3): 31-8.

Sovann, C., K. N. Irvine, S. Suthipong, S. Kok and E. Chea. 2015. "Dynamic Modeling to Assess Natural Wetlands Treatment of Wastewater in Phnom Penh, Cambodia: Towards an Eco-City Planning Tool." British Journal of Environment and Climate Change 5 (2): 104-15.

Takeuchi, T., Y. Takahashi and C. Sina. 2005. "Sewage Water Quality of Phnom Penh City." Journal of Water and Environmental Technology 3:133-43.

Talei, A. and L. H. C. Chua. 2012. "Influence of Lag Time on EventBased Rainfall-Runoff Modeling Using the Data Driven Approach." Journal of Hydrology 438-439:223-33.

Turner, K. R., S. Georgio and B. Fisher. 2011. Valuing Ecosystem Services, the Case of Multi-Functional Wetlands. Washington, DC: Earthscan.

Tzoulas, K., K. Korpela, S. Venn, V. Yli-Pelkonen, A. Kazmierczak, J. Niemela and P. James. 2007. “Promoting Ecosystem and Human Health in Urban Areas Using Green Infrastructure: A Literature Review." Landscape and Urban Planning 81:167-78.

van Leeuwen, C. J. 2013. “City Blueprints: Baseline Assessments of Sustainable Water Management in 11 Cities of the Future." Water Resources Management 27:5191-206.

van Leeuwen, C. J., J. Frijns, A. van Wezel and F. H. M. van de Ven. 2012. “City Blueprints: 24 Indicators to Assess the Sustainability of the Urban Water Cycle." Water Resources Management 26 :2177-97.

Varis, O., A. K. Biswas, C. Tortajada and J. Lundqvist. 2006. "Megacities and Water Management." Water Resources Development 22(2): 377-394.

Varis, O., M. Kummu, M. Keskinen, J. Sarkkula, J. Koponen, U. Heinonen and K. Makkonen. 2006. "Integrated Water Resources Management on the Tonle Sap Lake, Cambodia." Water Science \& Technology: Water Supply 6 (5): 51-8.

Visoth, T., M. Yim, S. Vathna, K. Irvine and T. Koottatep. 2010. “Efficiency of Phnom Penh's Natural Wetlands in Treating Wastewater Discharges." Asian Journal of Water, Environment and Pollution 7(3): 39-48

Visvanathan, C. 2011. Present Status of Sewage Dissemination in Thailand and the Applicability of UASB-DHS (Upflow Anaerobic Sludge Blanket Down-Flow Hanging Bed Sponge) Technology to Thailand. Report, Environmental Engineering and Management. Pathumthani, Thailand: Asian Institute of Technology.

Vlahov, D., N. Freudenberg, F. Proietti, D. Ompad, A. Quinn, V. Nandi and S. Galea. 2007. "Urban as a Determinant Of Health." Journal of Urban Health 84 (1): 16-26.

Vuong, T. A., T. T. Nguyen, L. T. Klank, D. C. Phung and A. Dalsgaard. 2007. “Faecal and Protozoan Parasite Contamination of 
Water Spinach (Ipomoea aquatica) Cultivated in Urban Wastewater in Phnom Penh, Cambodia." Tropical Medicine and International Health 12 (2): 73-81.

Weldesilassie, A. B., P. Amerasinghe and G. Danso. 2011. “Assessing the Empirical Challenges of Evaluating the Benefits and Risks of Irrigating with Wastewater." Water International 36 (4): 441-54.

Wittig, R. 2008. "Principles for Guiding Eco-City Development." In Ecology, Planning and Management of Urban Forests, edited by M. M. Carreiro, Y.-C. Song and J. Wu, 29-34. New York: Springer.

Whittington, D. 1998. "Administering Contingent Valuation Surveys in Developing Countries." World Development 26 (1): 21-30.

Wichelns, D., M. Owaygen and M. Redwood. 2011. “Developing Country Farmers Need More than Financial Incentives to
Reduce the Risks of Wastewater Irrigation." Water International 36 (4): 467-75.

Wong, T.-C. and B. Yuen (eds). 2011. Eco-City Planning, Policies, Practice and Design. New York: Springer.

Yokohari, M., K. Takeuchi, T. Watanabe and S. Yokota. 2000. “Beyond Greenbelts and Zoning: A New Planning Concept for the Environment of Asian Mega-Cities." Landscape and Urban Planning 47:159-71.

Zhao, S., C. Peng, H. Jiang, D. Tian, X. Lei and X. Zhou. 2006. "Land Use Change in Asia and the Ecological Consequences." Ecological Research 21 (6): 890-6. 